\title{
Trade and the Great Divergence: The Family Connection
}

\author{
Oded Galor and Andrew Mountford*
}

January 9, 2006

\begin{abstract}
This research argues that the rapid expansion of international trade in the second phase of the industrial revolution has played a major role in the timing of demographic transitions across countries and has thereby been a significant determinant of the distribution of world population and a prime cause of the 'Great Divergence' in income per capita across countries in the last two centuries. The analysis suggests that international trade had an asymmetrical effect on the evolution of industrial and non-industrial economies. While in the industrial nations the gains from trade were directed primarily towards investment in education and growth in output per capita, a significant portion of the gains from trade in non-industrial nations was channeled towards population growth.

Keywords: International Trade, Demographic Transition, Industrial Revolution, Growth, Human Capital
\end{abstract}

JEL Classification Numbers: O40, F11, F43, J10, N30

*Oded Galor, Department of Economics, Brown University, Providence, RI 02912,USA. E-mail: Oded_Galor@Brown.edu. Galor's research was supported by NSF grant SES-0004304. Andrew Mountford, Department of Economics, Royal Holloway, University of London, Egham, Surrey, TW20 0EX, UK. E-mail: A.Mountford@rhul.ac.uk. 
The last two centuries have been characterized by dramatic changes in the distribution of income and population across the globe. While Western European economies have tripled their domination in terms of income per capita over Asian economies, significant resources in Asian countries have been channeled into doubling their lead over Western Europe in the population dimension.

This research argues that the rapid expansion of international trade in the second phase of the industrial revolution has played a major role in the timing of demographic transitions across countries and has thereby been a significant determinant of the distribution of world population and a prime cause of the 'Great Divergence' in income per capita across countries in the last two centuries. The analysis suggests that international trade had an asymmetrical effect on the evolution of industrial and non-industrial economies. While in the industrial nations the gains from trade were directed primarily towards investment in education and growth in output per capita, a significant portion of the gains from trade in non-industrial nations was channeled towards population growth.

In the second phase of the Industrial Revolution, international trade enhanced the specialization of industrial economies in the production of industrial, skilled intensive, goods. The associated rise in the demand for skilled labor induced an investment in the quality of the population, expediting their demographic transition, stimulating technological progress and further enhancing the comparative advantage of these industrial economies in the production of skilled intensive goods. In non-industrial economies, in contrast, international trade generated an incentive to specialize in the production of unskilled intensive, non-industrial, goods. The absence of a significant demand for human capital provided limited incentives to invest in the quality of the population and the gains from trade were utilized primarily for a further increase in the size of the population. The demographic transition in these non-industrial economies was significantly delayed, increasing further their relative abundance of unskilled labor, enhancing their comparative disadvantage in the production of skilled intensive goods and delaying their process of development. Thus, the historical patterns of international trade reinforced the initial patterns of comparative advantage and generated a persistent effect on the distribution of population in the world economy and a great divergence in income per capita across countries and regions. 
In contrast to the literature on growth and comparative advantage,${ }^{1}$ the focus on the interaction between population growth and comparative advantage and the persistent effect that this interaction may have on the distribution of population and income in the world economy generates an important new insight regarding the distribution of the gains from trade. The theory suggests that even if trade equalizes output growth in the trading countries, (due to the terms of trade effect), income per capita of developed and less developed economies will diverge since in less developed economies the growth of total output will be generated more significantly by population growth, whereas in developed economies it will be generated primarily by an increase in output per capita.

The proposed hypothesis is consistent with the evidence about the effect of trade on industrialization, the rise in the demand for human capital in the second phase of industrialization, the effect of human capital formation on the demographic transition, and the forces behind the transition from stagnation to growth. ${ }^{2}$

\section{An Autarkic Economy}

Consider a perfectly competitive overlapping-generations economy. In each period $t$, two goods, an industrial good, $Y_{t}^{m}$, and an agricultural good, $Y_{t}^{a}$, may be produced using two factors of production: skilled labor, $H_{t}$, and unskilled labor, $L_{t}$. The adult population, $N_{t}$ and its decomposition between skilled and unskilled workers evolve endogenously over time.

\section{A. Production}

The output of the agricultural good produced in period $t, Y_{t}^{a}$, is

$$
Y_{t}^{a}=A^{a} L_{t}^{a}
$$

where $A^{a}$ is the productivity level, and $L_{t}^{a}$ is the level of employment of unskilled labor, in the agricultural sector in period $t$.

\footnotetext{
${ }^{1}$ E.g., Ronald Findlay and Henryk Kierzkowski (1983), Gene Grossman and Elhanan Helpman (1991), Kiminori Matsuyama (1992), Alwyn Young (1991), and Nancy Stokey (1991).

${ }^{2}$ This historical evidence is surveyed by Oded Galor (2005). See also, Joel Mokyr (1990), Galor and David N. Weil (2000), Galor and Omer Moav (2002), Robert E. Lucas (2002), Antoni Estavadeordal, Brian Frantz and Alan M. Taylor (2003), Galor and Andrew Mountford (2003), Matthias Doepke (2004), and Kevin H. O'Rourke and Jeffrey G. Williamson (2005).
} 
The output of the industrial good produced in period $t, Y_{t}^{m}$, is

$$
Y_{t}^{m}=A_{t}^{m}\left(H_{t}\right)^{\gamma}\left(L_{t}^{m}\right)^{1-\gamma}=A_{t}^{m} L_{t}^{m}\left(h_{t}^{m}\right)^{\gamma}, \quad 0<\gamma<1
$$

where $A_{t}^{m}$ is the productivity level, and $L_{t}^{m}$ and $H_{t}$ are the levels of employment of unskilled and skilled labor, in the industrial sector in period $t ; h_{t}^{m} \equiv H_{t} / L_{t}^{m}$.

As long as both goods are produced, the inverse demand for unskilled labor in the agricultural sector is $w_{t}^{u}=p_{t} A^{a}$, and in the industrial sector is $w_{t}^{u}=(1-\gamma) A_{t}^{m}\left(h_{t}^{m}\right)^{\gamma}$, and the inverse demand for skilled labor is $w_{t}^{s}=\gamma A_{t}^{m}\left(h_{t}^{m}\right)^{\gamma-1}$, where $w_{t}^{u}$ and $w_{t}^{s}$ are the wages of unskilled and skilled labor, and $p_{t}$ is the relative price of the agricultural good in terms of the industrial good, in period $t$. Since unskilled workers are perfectly mobile between the agricultural and the industrial sectors, the wages of unskilled labor in both sectors are equal if both goods are produced. Thus $p_{t}=(1-\gamma)\left(h_{t}^{m}\right)^{\gamma}\left(A_{t}^{m} / A^{a}\right)$.

\section{B. Individuals}

Individuals live for two periods. In their first period of life they consume a fraction of their parental unit time endowment. In their second period of life they are endowed with one unit of time which they allocate between child rearing and labor force participation.

An adult in period $t$ generates utility, $u_{t}$, from the consumption of the agricultural good, $c_{t}^{a}$, and the industrial good, $c_{t}^{m}$, and the total potential income of their children. In particular,

$$
u_{t}=\alpha \ln c_{t}^{a}+\beta \ln c_{t}^{m}+(1-\alpha-\beta) \ln \left(w_{t+1}^{s} n_{t}^{s}+w_{t+1}^{u} n_{t}^{u}\right)
$$

where $n_{t}^{s}$ and $n_{t}^{u}$ are the number of children trained to be skilled and unskilled workers, and $w_{t+1}^{s}$ and $w_{t+1}^{u}$ are their wages in period $t+1$.

The budget constraint of an adult $i$ (skilled or unskilled) in period $t$, is

$$
p_{t} c_{t}^{a}+c_{t}^{m}+w_{t}^{i}\left(n_{t}^{s} \tau^{s}+n_{t}^{u} \tau^{u}\right) \leq w_{t}^{i}
$$

where $\tau^{s}$ and $\tau^{u}$ is the time required to raise skilled and unskilled offspring respectively; $\tau^{s}>\tau^{u}$.

Given the homotheticity of the utility function, the optimal consumption of each good and the time devoted to child rearing have constant budget shares. In particular, $c_{t}^{a}=\alpha w_{t}^{i} / p_{t}$, $c_{t}^{m}=\beta w_{t}^{i}$, and $\left(n_{t}^{s} \tau^{s}+n_{t}^{u} \tau^{u}\right)=(1-\alpha-\beta)$ where

$$
n_{t}^{s}>0 \text { and } n_{t}^{u}>0 \quad \text { only if } \quad w_{t+1}^{s} / w_{t+1}^{u}=\tau^{s} / \tau^{u} .
$$




\section{Technological Progress}

Technological progress in the industrial sector between periods $t$ and $t+1, g_{t+1}$, is affected positively by the skill abundance, $h_{t} \equiv H_{t} /(\alpha+\beta) N_{t}$, in the labor force in period $t$.

$$
g_{t+1} \equiv \frac{A_{t+1}^{m}-A_{t}^{m}}{A_{t}^{m}}=g\left(h_{t}\right)
$$

where $g\left(h_{t}\right)$ is strictly positive, increasing concave function. ${ }^{3}$

\section{The Autarkic Equilibrium}

In autarky, since both goods are desired by consumers, they are produced. The demand for skilled and unskilled labor is therefore strictly positive and as follows from (5) $w_{t+1}^{s} / w_{t+1}^{u}=\tau^{s} / \tau^{u}$. Hence, the ratio of skilled and unskilled labor employed in the industrial sector is unique and constant over time:

$$
H_{t} / L_{t}^{m}=\gamma \tau^{u} /(1-\gamma) \tau^{s} \equiv \hat{h}^{m}
$$

The autarkic relative price of the agricultural good in period $t, p_{t}=(1-\gamma)\left(\hat{h}^{m}\right)^{\gamma}\left(A_{t}^{m} / A^{a}\right)$. is therefore increasing over time due to technological progress in the industrial sector.

The employments of unskilled labor in each of the two sectors, $L_{t}^{a}=\alpha /[(1-\gamma)+\gamma \alpha /(\alpha+$ $\beta)] L_{t}$, and $L_{t}^{m}=\beta /[1+(\alpha \gamma /(1-\gamma)(\alpha+\beta))] L_{t}$, are fixed fractions of the number of unskilled workers in the period $L_{t}$, and since $H_{t}=L_{t}^{m} \hat{h}^{m}$, the employment of skilled labor is a fixed fraction of $L_{t}$ as well. Moreover, the skill abundance in the labor force, $h_{t} \equiv H_{t} /(\alpha+\beta) N_{t}$, is constant over time. Thus, the economy is in a state of a balanced growth with constant rates of growth of technology, population, and income per capita.

\section{International Trade}

Consider a world consisting of two economies that are identical in every respect except that economy $A$ is more technologically advanced than economy $B$. Since technological advancement is biased towards the industrial sector, the autarkic relative price of the agricultural good in the technologically advanced economy, $A, p^{A}$, is higher, i.e., $p^{A}>p^{B}$.

\footnotetext{
${ }^{3}$ Technological progress in the agricultural sector will not affect the qualitative results as long as it is slower than that in the industrial sector.
} 
When international trade is established the international equilibrium price, $p_{t}^{*}$, is $p_{t}^{B} \leq$ $p_{t}^{*} \leq p_{t}^{A}$. Suppose that initially $p_{t}^{B}<p_{t}^{*}<p_{t}^{A}$. The technologically advanced economy $A$ specializes in the production of the industrial good, producing $(\alpha+\beta)\left(\hat{h}^{m}\right)^{\gamma}\left[A_{t}^{m}\right]^{A} L_{t}^{A}$ and exporting $\alpha\left(\hat{h}^{m}\right)^{\gamma}\left[A_{t}^{m}\right]^{A} L_{t}^{A}$ units of the good. Economy $B$ specializes in the production of the agricultural good, producing $(\alpha+\beta)\left[A^{a}\right]^{B} L_{t}^{B}$ and exporting $\beta\left[A^{a}\right]^{B} L_{t}^{B}$ units of the good. The international equilibrium price is therefore,

$$
p_{t}^{*}=\frac{\alpha\left(\hat{h}^{m}\right)^{\gamma}\left[A_{t}^{m}\right]^{A} L_{t}^{A}}{\beta\left[A^{a}\right]^{B} L_{t}^{B}}
$$

\section{A. Trade, Fertility and Education}

Economy $A$ completely specializes in the production of the industrial good and its demand for skilled workers increases. This induces investment in children's quality and thus, given the constant fraction of time devoted to child rearing, it decreases fertility to $\left(n^{A}\right)^{*}=(1-\alpha-\beta)(1-\gamma(1-$ $\left.\left.\tau^{u} / \tau^{s}\right)\right) / \tau^{u}$. The skill abundance in economy $A$ rises to $\left(h^{A}\right)^{*}=\hat{h}^{m} /\left(\hat{h}^{m}+1\right)$ and its rate of technological progress therefore increases relative to autarky.

In contrast, economy $B$ completely specializes in the production of the agricultural good, eliminating the demand for skilled workers. Its fertility rate rises to $\left(n^{B}\right)^{*}=(1-\alpha-\beta) / \tau^{u}>\left(n^{A}\right)^{*}$, its skilled intensity decreases to $\left(h^{B}\right)^{*}=0$, and its technological progress therefore decreases relative to autarky.

\section{B. Trade on Economic Growth}

Proposition 1 If international trade induces economies $A$ and $B$ to completely specialize in production, the growth rate in the value of total output in economy $A,\left(n^{A}\right)^{*}\left[1+g\left(\left(h^{A}\right)^{*}\right)\right]-1$, is equal to that in economy $B$.

Proof. Since economy $B$ specializes in the production of the agricultural good, the value of its output is $p_{t}^{*}\left(Y_{t}^{a}\right)^{B}=p_{t}^{*}\left(A^{a}\right)^{B} L_{t}^{B}(\alpha+\beta)$. Since $A$ specializes in the production of the industrial good, the value of its output is $\left(Y_{t}^{m}\right)^{A}=\left[A_{t}^{m}\right]^{A}\left(\hat{h}^{m}\right)^{\gamma} L_{t}^{A}(\alpha+\beta)$. Thus noting (7) the growth rates of the value of total output of the two economies are equal.

Thus, the improvements in the terms of trade of economy $B$ offset the differential productivity in the two economies, enabling the value of total output in the two economies to grow at 
the same rate.

Corollary 1 Although international trade equalizes the growth rates of the value of total output in the two trading economies, since the rate of population growth in the technologically regressed economy, $B,\left(n^{B}\right)^{*}-1$, is higher than the rate of population growth in the technologically advanced economy, $A,\left(n^{A}\right)^{*}-1$, i.e.,

$$
\left(n^{B}\right)^{*}-1>\left(n^{A}\right)^{*}-1,
$$

the rate of growth of output per capita in the technologically advanced economy $A,\left(g_{y}^{A}\right)^{*}$, is higher than the rate of growth of output per capita in country $B,\left(g_{y}^{B}\right)^{*}$, i.e.,

$$
\left(g_{y}^{A}\right)^{*}=g\left(\left(h^{A}\right)^{*}\right)>\left(g_{y}^{B}\right)^{*}=\left[1+g\left(\left(h^{A}\right)^{*}\right)\right]\left[\left(n^{A}\right)^{*} /\left(n^{B}\right)^{*}\right]-1
$$

\section{The Evolution of the World Economy}

Complete specialization in production will be maintained as long as $p_{t}^{B}<p_{t}^{*}<p_{t}^{A}$, i.e., as long as

$$
\frac{(1-\gamma)\left[A_{t}^{m}\right]^{B}}{\left[A^{a}\right]^{B}}<\frac{\alpha\left[A_{t}^{m}\right]^{A} L_{t}^{A}}{\beta\left[A^{a}\right]^{B} L_{t}^{B}}<\frac{(1-\gamma)\left[A_{t}^{m}\right]^{A}}{\left[A^{a}\right]^{A}} .
$$

Hence, economy $B$ will diversify its production once the left inequality is violated, whereas economy $A$ will diversify its production if the right inequality is violated. Since $\left(L_{t}^{A} / L_{t}^{B}\right)$ declines over time, (i.e., $\left.\left(n^{B}\right)^{*}>\left(n^{A}\right)^{*}\right)$, the right inequality cannot be violated and economy $A$ remains completely specialized. However, if population growth in economy $B$ is sufficiently large then eventually it becomes diversified in production. Trade causes fertility to rise in economy $B$ and to decrease in economy $A$. Once economy $B$ becomes diversified in production its fertility rate and technological growth rate tend towards their autarkic levels. Although the growth rate of total output will not be equal in the two economies, the fraction of the overall growth that will be attributed to population growth will be smaller in the technologically advanced economy.

\section{Conclusion}

This research argues that the Great Divergence in income per capita across countries can be attributed, in part, to the contrasting effects that the rapid expansion of international trade in the second phase of the industrial revolution had on the demand for human capital and thus on 
the timing of the demographic transition in industrial and non-industrial countries. The gains from trade were channeled predominantly towards an increase in income per capita in industrial economies and more significantly towards an increase in population in non-industrial economies.

The adverse effect of international trade on industrialization and thus on the timing of the demographic transition in less developed economies could have been mitigated by the positive effect of trade on technological diffusion across countries. However, labor productivity in this period differed greatly across countries even among industries in which technologies were similar across the globe (Gregory Clark (1987)). Moreover, since the rate of technological diffusion depends upon the appropriateness of factor endowments in the receiving country, the adverse effect of trade on factor endowments of less developed economies would reduce the rate of technological diffusion.

The onset of the demographic transition in most countries in the world, along with the acceleration in technological diffusion and the changes in the nature of international trade and its effect on the return to human capital, suggest that although trade may have had an adverse effect on the earlier process of industrialization in less developed countries, the conventional beneficial forces that are associated with international trade have dominated in recent decades. 


\section{REFERENCES}

Clark, Gregory "Why Isn't the Whole World Developed?: Lessons from the Cotton Mills." Journal of Economic History, 1987, 47 (1), pp. 141-174.

Doepke, Matthias. "Accounting for Fertility Decline During the Transition to Growth." Journal of Economic Growth, 2004, 9 (3), pp. 347-383.

Estavadeordal, Antoni, Frantz, Brian and Taylor, Alan M. "The Rise and Fall of World Trade, 1870-1939." Quarterly Journal of Economics, 2003, 118 (2), pp. 359-407.

Findlay, Ronald and Keirzkowsky, Henryk. "International Trade and Human Capital: A Simple General Equilibrium Model.” Journal of Political Economy, 1983, 91 (6), pp. 957-978.

Galor, Oded, "From Stagnation to Growth: Unified Growth Theory" in Aghion, Phillipe, and Durlauf, Steven N, eds, Handbook of Economic Growth, Volume 1A. Amsterdam: Elsevier NorthHolland, 2005, pp. 172-293.

Galor, Oded and Moav, Omer. "Natural Selection and the Origin of Economic Growth." Quarterly Journal of Economics, 2002, 117 (4), pp. 1133- 1191.

Galor, Oded and Mountford, Andrew. "Trading Population for Productivity", Unpublished paper, 2003.

Galor, Oded and Weil, David N. "Population, Technology and Growth: From the Malthusian Regime to the Demographic Transition." American Economic Review, 2000, 90 (4), pp. 806-828.

Grossman, Gene M. and Helpman, Elhanan. Innovation and Growth. Cambridge MA: MIT Press, 1991.

Lucas, Robert. E. Jr. The Industrial Revolution: Past and Future Cambridge MA: Harvard University Press, 2002.

Matsuyama, Kiminori. "Agricultural Productivity, Comparative Advantage, and Economic Growth.” Journal of Economic Theory, 1992, 58 (2), pp. 317-334.

Mokyr, Joel. The Lever of Riches. New York NY: Oxford University Press, 1990.

O'Rourke, Kevin H. and Williamson, Jeffrey G. "From Malthus to Ohlin: Trade, Industri- 
alization and Distribution since 1500." Journal of Economic Growth, 2005, 10 (1), pp. 5-34.

Stokey Nancy. "The Volume and Composition of Trade Between Rich and Poor Countries." Review of Economic Studies, 1991, 58 (1), pp. 63-80.

Young Alwyn. "Learning by Doing and the Dynamic Effects of International Trade." Quarterly Journal of Economics, 1991, 106 (2), pp. 369-405. 